\title{
Contraceptive Coverage Laws: Eliminating Gender Discrimination or Infringing on Religious Liberties?
}

\author{
Inimai M. Chettiar $\dagger$
}

To ensure that women receive access to contraceptives, state legislatures have recently enacted measures requiring insurers to cover contraceptives under their insurance plans. ' Congress is considering a similar law that would require insurance plans to provide the same level of coverage for all FDA-approved prescription contraceptives and related outpatient services as they provide for other prescription drugs and preventive care. ${ }^{2}$ Currently, most insurance plans cover preventive prescription drugs yet do not cover contraceptive drugs and devices. ${ }^{3}$ Legislatures passed these contraceptive coverage laws, therefore, to eliminate this gender discrimination.

Some religious employers and insurers, however, believe that the use of contraception is a sin and that assisting another person to commit a sin is a sin itself.' They claim that contraceptive coverage laws inhibit their free exercise of religion in violation of the First Amendment. ${ }^{6}$ Out of respect for these employers and insurers, some legislatures included exemptions (also called "conscience provisions") for those entities that object to contraception on religious grounds.'

Some employers and insurers that object to coverage based on religious grounds, however, may not fall within the statutory exemptions. For example, Catholic Charities, a public benefits corporation

$\dagger$ B.A. 1998, Georgetown University; J.D. Candidate 2003, The University of Chicago.

1 See, for example, An Act Concerning Health Benefit Plans-Coverage for Prescription Contraceptive Drugs or Devices, 1998 Md Laws 117, codified at Md Ins Code Ann § 15-826 (Supp 2001). Maryland was the first state to pass a contraceptive coverage law. See also Part II.

2 See Equity in Prescription Insurance and Contraceptive Coverage Act ("EPICC"), HR 1111, 107th Cong, 1st Sess (Mar 20, 2001); S 104, 107th Cong, 1st Sess (Jan 22, 2001). EPICC is currently before the Senate Health, Education, Labor, and Pensions Committee, available online at <http:/thomas.loc.gov/bss/d107query.html> (visited Apr 25, 2002). The last action taken was a hearing before the Committee on September 10,2001. See id.

3 See text accompanying note 62 .

4 See Part II.A.

5 See, for example, Catholic Charities of Sacramento, Inc v Superior Court of Sacramento County, 109 Cal Rptr 2d 176, 184 (App 2001) (recognizing that the Catholic religion believes that both contraceptive use and the facilitation of such use are sins), cert granted, $112 \mathrm{Cal}$ Rptr $2 \mathrm{~d} 258$ (2001).

6 See id. See also US Const Amend I ("Congress shall make no law ... prohibiting the free exercise [of religion].").

7 See Part II.B. 
that provides social benefits to beneficiaries of all faiths, does not fit within the California statutory exemption; however, providing contraceptive benefits to its employees violates Catholic Charities' religious beliefs. $^{8}$ On the other hand, a Catholic church would be exempt from California's law.'

Entities such as Catholic Charities have at least two constitutional claims. The first claim is based on the Establishment Clause: By exempting only certain employers, the state has endorsed the beliefs of the exempted employers' religions and "established" those religions. ${ }^{10}$ The other is grounded in the Free Exercise Clause: By failing to exempt the employer the law forces the employer to provide contraceptive benefits even when providing such benefits is against the employer's religious beliefs.

This Comment assesses the constitutionality of state contraceptive coverage laws under the Free Exercise Clause, examining both laws with exemptions for religious insurers and employers and laws without such exemptions. Only one state appellate court has reviewed whether a contraceptive coverage law violates the Free Exercise Clause." The California appellate court decision, which upheld the law, is currently before the California Supreme Court. ${ }^{2}$

Whether a contraceptive coverage law violates the Free Exercise Clause depends on to whom the law applies. The analysis turns on whether the law contains an exemption and, if so, which entities the law exempts. Under Supreme Court precedent, laws without exemptions, which are laws that require all employers to offer contraceptive coverage, do not violate the First Amendment's Free Exercise Clause because they are neutral and generally applicable.

8 See Catholic Charities, 109 Cal Rptr 2d at 183-84, 206 (upholding a contraceptive coverage law against a challenge by Catholic Charities). Catholic Charities does not fit within the scope of California's exemption because: (1) it does not inculcate those it serves with its religious beliefs, (2) 74 percent of its employees are not Catholic, (3) it offers social services to people of all faiths, and (4) it is a nonprofit public benefit organization exempt from federal income tax pursuant to Section 501(c)(3) of the Internal Revenue Code, rather than Section 6033(a)(2)(A)(i) or (iii) of that Code. See id at 184; Cal Health \& Safety Code $\$ 1367.25(b)(1)$ (West Supp 2002). See also note 98.

9 See Catholic Charities, 109 Cal Rptr 2d at 184.

10 See Larson $v$ Valente, 456 US 228, 255 (1982) (holding that a state law imposing registration requirements on solicitors but exempting religious organizations that solicit 50 percent or less of their funds from nonmembers violated the Establishment Clause by favoring majority or popular religions over new or minority religions).

11 See Catholic Charities, 109 Cal Rptr 2d at 176.

12 See Catholic Charities of Sacramento, Inc v Superior Court of Sacramento County, 112 Cal Rptr 2d 258 (2001). The case has been fully briefed. See California Supreme Court website, $<$ http://appellatecases.courtinfo.ca.gov> (visited Aug 10,2002).

13 See Part III. 
The constitutionality of laws with exemptions, however, is more complex because the scope of the exemptions varies by state. ${ }^{14}$ Some states exempt only certain religious entities. This Comment refers to these as "selective exemptions.". For example, California's statute exempts a religious employer only if the employer has a purpose of inculcating religious values, primarily employs persons who share its religious tenets, primarily serves persons who share its religious tenets, and qualifies as a nonprofit organization. ${ }^{16}$ Other states exempt all religious entities that choose to be exempted. This Comment will refer to these as "broad exemptions." "For example, Maryland's statute exempts any religious organization if coverage "conflicts with [its] bona fide religious beliefs and practices." ${ }^{18}$

Part I of this Comment explains the Supreme Court's two Free Exercise Clause tests. Part I.A lays out the first test: If a law that infringes on religious liberties is not neutral or not generally applicable, then it must survive strict scrutiny-it must be narrowly tailored to fulfill a compelling government interest. ${ }^{19}$ Part I.B explains the second test: If a law is neutral and generally applicable, it need not provide any religious exemption to be constitutional. ${ }^{20}$ Part II presents an overview of state contraceptive coverage legislation. Part II.A focuses on the laws' requirements. Part II.B examines the scope of the various exemptions, dividing them into three categories: no exemption, broad exemptions, and selective exemptions. This Part also clarifies that contraceptive coverage laws with broad religious exemptions do not pose a free exercise threat to the rights of religious employers and insurers and will therefore not be addressed in this Comment's free exercise analysis.

Part III and Part IV propose a multipart framework for courts to apply when evaluating whether contraceptive coverage laws violate the free exercise rights of religious insurers and employers. Part III argues that state laws without religious exemptions are constitutional because they are neutral laws of general applicability. Part IV focuses on contraceptive coverage laws with selective exemptions. Part IV.A argues that state laws with selective exemptions are not generally applicable; therefore, these laws must survive strict scrutiny to pass constitutional muster. Part IV.B.1 asserts that contraceptive coverage laws

14 See Part II.B.

15 See Part II.B.3.

16 Cal Health \& Safety Code $\$ 1367.25(b)(1)$.

17 See Part II.B.2.

18 Md Ins Code Ann \$ 15-826(c) (Supp 2001).

19 The Supreme Court clarified this test in Church of Lukumi Babalu Aye v City of Hialeah, 508 US 520, 546-47 (1993), and Sherbert v Verner, 374 US 398, 402-03 (1963).

20 The Supreme Court created this test in Employment Division, Department of Human Resources v Smith, 494 US 872, 878-79 (1990). 
in general, and selective exemptions in particular, serve the compelling state interest of eradicating gender discrimination against female employees, and this interest is sufficient to overcome the employers' and insurers' free exercise rights. Part IV.B.2 argues that selective exemptions are narrowly tailored to serve that interest because they either include a "categorical exemption" (approved by the Court in previous cases) or because they focus on the object of the compelling interest-ending gender discrimination in insurance benefits provided to employees.

\section{THE SUPREME COURT'S FREE EXERCISE JURISPRUDENCE}

The First Amendment's Free Exercise Clause prohibits federal and state governments from interfering with or attempting to regulate an individual's religious beliefs. If an individual or entity claims to hold a sincere religious belief, a court cannot question the claim's sincerity. The Free Exercise Clause protects religious organizations as well as individuals. ${ }^{23}$

This Part first discusses the strict scrutiny test, which Part IV will argue applies to contraceptive coverage laws with exemptions. Part I.B then turns to the test created in Employment Division, Department of Human Resources $v$ Smith, which applies to contraceptive coverage laws without exemptions.

\section{A. The Strict Scrutiny Test}

Although freedom of individual religious belief is absolute, freedom of individual conduct motivated by religious belief is not unconditionally protected. ${ }^{26}$ To determine the constitutional reach of state-

21 See School District of Abington Township v Schempp, 374 US 203, 222-23 (1963) ("The Free Exercise Clause ... withdraws from legislative power, state and federal, the exertion of any restraint on the free exercise of religion."); Cantwell v Connecticut, 310 US 296, 303 (1940) (holding that the Free Exercise Clause applies to states through the Fourteenth Amendment).

22 See Thomas $v$ Review Board of Indiana Employment Security Division, 450 US 707, 71516 (1981) ("[T] he guarantee of free exercise is not limited to beliefs which are shared by all of the members of a religious sect.... [I]t is not within the judicial function and judicial competence to inquire [who has] more correctly perceived the commands of their common faith.").

23 See, for example, Church of the Lukumi Babalu Aye v City of Hialeah, 508 US 520, 54243 (1993) (applying the Free Exercise Clause to protect a church).

24494 US $872,878-79$ (1990) (finding that a law of general applicability is binding even upon those whose religious beliefs are contrary to the law).

25 See Part III (arguing that laws without exemptions pass the Smith test).

26 See Bowen v Roy, 476 US 693, 699-700 (1986) (holding that the government need not comply with an individual's claim that making his Social Security number available violated his religious beliefs). One could argue that only laws without exemptions are subject to this two-part inquiry because in Smith the court was faced with judicially creating an exemption, not with the constitutionality of a pre-existing statutory exemption. However, this is the Court's only framework for free exercise claims. Therefore, any litigant requesting a free exercise exemption from a 
created limitations on religious conduct, the Supreme Court in 1973 established a test of strict scrutiny in Sherbert $v$ Verner. ${ }^{27}$ This test was further refined in Church of Lukumi Babalu Aye $v$ City of Hialeah. ${ }^{25}$ Under strict scrutiny, a law that infringes on religious liberties must be justified by a compelling governmental interest and must be narrowly tailored to advance that interest. ${ }^{29} \mathrm{~A}$ compelling interest must be of the "highest order";" "no showing merely of a rational relationship to some colorable state interest [will] suffice; . . . '[o]nly the gravest abuses, endangering paramount interests, give occasion for permissible limitation." "' Lukumi clarified that, if a law contains a system of individualized exemptions, the government "may not refuse to extend [exemptions] to cases of 'religious hardship' without compelling reason." That is, the scope of the exemption must be narrowly tailored to fulfill a compelling interest. ${ }^{33}$

The Court has not formulated a comprehensive test to decide which interests are compelling and therefore justify restrictions of religious practice, and which are not; rather, the Court has addressed each case on an ad hoc basis. Take Lukumi for example. Presented with the public health rationale offered by the city council, the Court found no compelling reason for ordinances to distinguish between the

law must survive this two-part test regardless of whether the litigant is asking for the court to create a new exemption or to extend an existing statutory exemption.

27374 US 398, 402-03 (1963). See also Lukumi, 508 US at 531. In Sherbert, a state unemployment agency denied a Seventh Day Adventist unemployment benefits. 374 US at $400-$ 01. The agency determined that the claimant's refusal to work on Saturday, which was based on her religious beliefs, was not "good cause" and therefore disqualified her from receiving benefits. Id. 28 50S US 520,531-32 (1993). When applying strict scrutiny, Lukumi does not cite Sherbert. See id at 546. Instead, Lukumi cites McDaniel v Paty, 435 US 618, 628 (1978), and Wisconsin v Yoder, 406 US 205, 215 (1972). See 508 US at 546. These two cases, however, proceed from Sherbert.

29 See Lukumi, 508 US at 531-32; Sherbert, 374 US at 402-03. Lukumi clarified that not only must the law serve a compelling interest, but also that the law "must be narrowly tailored to advance that interest." 508 US at 531-32.

30 Lukumi, 508 US at 546, citing McDaniel v Paty, 435 US 618, 628 (1978), and Wisconsin v Yoder, 406 US 205, 215 (1972).

31 Sherbert, 374 US at 406, quoting Thomas v Collins, 323 US 516, 530 (1945). The Court in Sherbert held that prohibiting unemployment insurance claims based on fraudulent religious objections was not a compelling interest. See 374 US at 407.

32 See Lukumi, 508 US at 537, quoting Smith, 494 US at 884.

33 If the inquiry was whether the law served a compelling interest, then as long as contraceptive coverage laws served to eliminate gender discrimination, they could exempt a Catholic church, but not Catholic Charities, with no justification. If an exemption is selective, there must be a justification for that selectivity. Both Justice O'Connor and Justice Blackmun emphasized in their separate opinions in Smith that the failure to exempt must fulfill a compelling interest. See Smith, 494 US at 905 (O'Connor concurring); id at 907-08 (Blackmun dissenting). Note, however, that their disagreement with the majority did not concern the substance of the strict scrutiny test-whether the requirement of the law or the failure to exempt must be narrowly tailored to fulfill a compelling interest. Their disagreement concerned whether the strict scrutiny test should even be applied to the peyote law at issue in Smith (the majority held that it should not and the dissenters argued that it should). 
religiously motivated animal killings prohibited by the statute at issue and nonreligious ones that were permitted. ${ }^{34}$ In Frazee $v$ Illinois Department of Employment Security, ${ }^{35}$ the law at issue denied unemployment benefits to individuals who refused to work without good cause and provided an exemption only for individuals whose refusal was based on tenets of an organized religion. ${ }^{36}$ The court held that the state-proffered interest of preventing mass movement away from Sunday employment was not sufficiently compelling to justify the distinction between refusals based on personal religious belief versus organized religious belief. ${ }^{37}$

A law that infringes on free exercise rights must also be narrowly tailored. It can be neither substantially overinclusive nor underinclusive. ${ }^{38}$ When the government "restricts only conduct protected by the First Amendment and fails to enact feasible measures to restrict other conduct producing substantial harm or alleged harm of the same sort," the law is underinclusive. ${ }^{39}$ When narrower ordinances that burden religion to a far lesser degree could have fulfilled the same compelling interest, the law is overinclusive. ${ }^{40}$ After Sherbert, if a law that infringed on the right to free exercise of religion did not survive strict scrutiny, then the law violated the Free Exercise Clause.

\section{B. The Smith Test}

In Smith, the Supreme Court created an additional framework to assess the circumstances under which religiously motivated conduct may be limited. The Court held that a "neutral law of general applicability" need not be subject to strict scrutiny even if the law has the incidental effect of burdening a particular religious practice. ${ }^{41}$ However, the Court did not explain the terms "neutral" and "generally applicable." The Court noted, without further explanation, that the Oregon law at issue was neutral and generally applicable because it prohibited

34508 US at 546-47.

35489 US 829 (1989).

36 See id at $830-31,834-35$.

37 Id at 835 ("We are unpersuaded ... that there will be a mass movement away from Sunday employ if [petitioner] succeeds in his claim.").

38 See Lukumi, 508 US at 546 (holding that a law is not narrowly tailored if it "overbroad or underinclusive in substantial respects").

39 See id at $546-47$.

40 See id at 539 (finding that narrower regulation would have achieved the city's interest in preventing cruelty to animals).

41 See Smith, 494 US at 878-79, 885 (reasoning that the government's ability to enforce generally applicable prohibitions of socially harmful conduct "cannot depend on measuring the effects of a governmental action on a religious objector's spiritual development") (internal quotations and citations omitted). 
all citizens from using peyote and because it was not motivated by an attempt to regulate religious beliefs. ${ }^{42}$

Thus, under Smith, legislatures are not required to provide exemptions from neutral and generally applicable laws for religious activities, ${ }^{43}$ but legislatures may choose to include statutory exemptions. Although the facts of Smith concerned a criminal statute applied to an individual, ${ }^{45}$ courts have applied the Smith test to organizations ${ }^{46}$ and noncriminal statutes ${ }^{47}$ as well. ${ }^{43}$

42 See id at 882 (holding the law valid because "[t] there [is] no contention that Oregon's drug law represents an attempt to regulate religious beliefs"). For a general discussion of which laws courts have found to be neutral and of general applicability, see Robin Cheryl Miller, What Laws are Neutral and of General Applicability within Meaning of Employment Division, Department of Human Resources of Oregon v. Smith, 494 U.S. 872, 110 S. CT. 1595, 108 L. ED. $2 D$ 876,167 ALR Fed 663 (2001).

43 There is a plethora of scholarship criticizing Smith as underprotective of religious liberties. See, for example, James D. Gordon, Free Exercise on the Mountaintop, 79 Cal L Rev 91, 91 (1991) (arguing that Smith "mistreated precedent, used shoddy reasoning, and ... deprived the free exercise clause of any independent significance"); Kathleen P. Kelly, Note, Abandoning the Compelling Interest Test in Free Exercise Cases: Employment Division, Department of Human Resources v Smith, 40 Cath U L Rev 929, 933 (1991) (arguing that Smith "contradicts the purpose and intent of the Free Exercise Clause and abrogates the protection previously afforded individuals when exercising their religious beliefs").

44 See Smith, 494 US at 890 (recognizing that "a number of States have made an exception to their drug laws for sacramental peyote use"). Smith addressed whether a court should create an exemption in a statute that did not contain one (a "judicially-created exemption"). Courts reviewing contraceptive coverage laws with exemptions address whether these existing statutory exemptions ("legislatively-created exemptions") are constitutional.

An exemption not mandated by the Free Exercise Clause does not automatically violate the Establishment Clause. See Walz v Tax Commission of the City of New York, 397 US 664, 674 (1970) (finding that a general tax exemption for religious organizations not required under the Free Exercise clause did not violate the Establishment Clause). The Establishment Clause prohibits the government from setting up a church or passing laws that aid one religion, all religions, or prefer one religion over another. See Board of Education of Kiryas Joel Village School District $v$ Grumet, 512 US 687, 703 (1994) ("[The] principle at the heart of the Establishment Clause ... [is] that government should not prefer one religion to another, or religion to irreligion."). Whether a law violates the Establishment Clause is analyzed under a framework provided by Lemon v Kurtzman, 403 US 602, 612-13 (1971). This Comment addresses whether contraceptive coverage laws, both with and without exemptions, violate the Free Exercise Clause. Whether the laws with exemptions violate the Establishment Clause is a separate inquiry.

45 Smith, 494 US at 874.

46 The Supreme Court assumed the Smith test applies to organizations as well as individuals by using the test to protect the free exercise rights of churches. See, for example, Lukumi, 508 US at 533-35 (holding that an ordinance prohibiting religious sacrifice failed the Smith test in an action brought by the Santeria Church).

47 The circuit courts have concluded that Smith applies to civil statutes. See, for example, Thomas v Anchorage Equal Rights Commission, 165 F3d 692, 700 n 6 (9th Cir 1999) (explaining that because the Supreme Court invalidated the Religious Freedom Restoration Act ("RFRA"), 42 USC $\$ 2000 \mathrm{bb}(\mathrm{b})(1)$ (2001), as in conflict with Smith, the Court must have assumed that Smith, like the RFRA, applied to civil as well as criminal statutes); Cornerstone Bible Church v City of Hastings, 948 F2d 464, 472-73 (8th Cir 1991) (applying Smith to a church's challenge of a zoning ordinance).

4 In response to Smith, Congress enacted the RFRA, Pub L No 103-141, 107 Stat 1488 (1993), codified at 42 USC $\$ 2000 \mathrm{bb}(\mathrm{b})(1)$ (2001), which restored the compelling interest test of 
The Supreme Court later clarified the meaning of neutrality and general applicability - the touchstones of Smith-in Lukumi. ${ }^{49}$ A law is not neutral if "the object of the law is to infringe upon or restrict practices because of their religious motivation.. ${ }^{50}$ To determine the law's objective, the Court first examined the text of the law and, second, the motivation behind the law. ${ }^{\text {si }}$ Lukumi also explained that for a law to qualify as generally applicable, it must apply equally to all individuals and/or entities. ${ }^{52}$ The law may not be "substantially" underinclusive."

Under Lukumi, a court examining any state law that infringes on individuals' or entities' religious liberties applies a two-part framework. First, the court determines whether the law is neutral and generally applicable under Smith. If the law meets these two requirements, then it is constitutional. ${ }^{\text {s5 }}$ If the law is not neutral or not generally applicable, the court tests the law's validity through the strict scrutiny test and applies the test created by Sherbert and its progeny." Smith, Sherbert, and Lukumi are thus the controlling precedent for every free exercise claim. ${ }^{\text {sT }}$

Sherbert. However, the Supreme Court held that the RFRA was unconstitutional as applied to states because in passing it Congress exceeded its enforcement powers under the Fourteenth Amendment. See City of Boerne v Flores, 521 US 507, 529-36 (1997). The RFRA, however, may still apply to federal law, such as the EPICC, which infringes on freedom of religion. See Michael W. McConnell, John H. Garvey, and Thomas C. Berg, Religion and the Constitution 187-93 (forthcoming Aspen 2002) (explaining that this is an unresolved issue). See also note 2 and accompanying text.

49 See 508 US at 531-46. In Lukumi, a Santeria church challenged city ordinances that prohibited animal killings and contained exemptions that seemingly permitted all such killings except those that were religious. Id at 542-43.

$50 \quad$ Id at 533 .

51 See id at 533-42 (finding that the ordinances were not neutral because legislative history showed that the city council specifically targeted the Santeria practice).

52 See id at 543-45 (finding that the ordinances were not generally applicable because they applied "only against conduct motivated by religious belief").

53 Id at 543. The Court found the ordinances underinclusive because they failed to prohibit nonreligious animal killings that endangered the state's interests in public health and animal cruelty to the same degree as the Santeria sacrifice.

54 Id at 531 .

55 See id ("[O]ur cases establish the general proposition that a law that is neutral and of general applicability need not be justified by a compelling governmental interest even if the law has the incidental effect of burdening a particular religious practice.").

56 See id ("A law failing to satisfy these requirements must be justified by a compelling governmental interest and must be narrowly tailored to advance that interest.").

57 Part III applies the Smith test to laws without exemptions, showing that these laws pass the test. Part IV.A applies the Smith test to laws with exemptions, arguing that they fail the test. Because these laws fail the Smith test, Part IV.B applies strict scrutiny to them. 


\section{SURVEY OF STATE LEGISLATION ${ }^{\text {s8 }}$}

This Part surveys state contraceptive coverage laws, examining both the requirements of the legislation and the scope of any exemptions. The requirements fall into two categories. "Comprehensive mandates" require all private medical insurers to provide coverage of all FDA-approved contraceptive methods. "Limited mandates" either require only some insurers to provide coverage (the legislation usually distinguishes based on specific types of insurers or specific markets) and/or require coverage of only some contraceptive methods. ${ }^{50}$ This Comment focuses solely on the constitutionality of the comprehensive mandates.

Comprehensive mandates contain exemptions that vary as to who is exempted-insurers, employers, or neither. Whether these laws are constitutional under the Free Exercise Clause depends on the scope of each law's exemption. While some contraceptive coverage laws have no exemptions, others contain exemptions that encompass any religious organization ("broad exemptions"). Still other laws contain exemptions encompassing only certain religious organizations ("selective exemptions"). Each type of exemption must be independently scrutinized under the Free Exercise Clause. ${ }^{60}$

58 See generally Cynthia Dailard, Enacted State Contraceptive Coverage Measures (Alan Guttmacher Institute Sept 5,2001) (on file with author).

59 Twelve states have enacted limited mandates. Ten states' laws apply only to HMOs. Of these states, two (Minnesota and Oklahoma) require coverage of contraceptive drugs and devices. See Minn Stat Ann § 62Q.14 (West 1996); Okla Admin Code § 310:655-5-1(10)(A)(C) (West 2000). Eight states (Massachusetts, Michigan, Montana, New Jersey, North Dakota, Ohio, West Virginia, and Wyoming) require coverage of "family planning services." See 211 Mass Reg Code $\S 43.03$ (West 2001); Mich Comp Laws Ann $\$ 500.3501$ (West Supp 2001); Mont Code Ann $\S \S 33-31-102,33-31-202(1)(b), 33-31-402(1)$ (c) (2001), Mont Admin Code $\S 6.6 .2508(2)$ (d) (West 2001); NJ Admin Code $\$ 8: 38-5.4$ (West 2001); ND Admin Code $\$$ 45-06-07-06-2(d) (West 2001); Ohio Rev Code Ann \$\$ 1751.01(A)(7), 1751.01(N), 1751.05(A)(3) (West Supp 2001); W Va Code Ann $\S \S 33-25 A-2$ (Lexis Supp 2001), 33-25A-4, 33-25A-18 (Lexis 2000); 13 Wyo Rules $\S$ 7(c)(ii)(B) (2001). Some of these latter statutes could have been interpreted to mandate coverage of drugs and devices, but the respective state insurance departments chose not to interpret them as such. For example, Montana and West Virginia have defined "voluntary family planning services" only as actual medical services, such as counseling or IUD insertion/removal, thereby not requiring coverage of the contraceptive drug or device.

Additionally, three states (Colorado, Kentucky, and New Jersey) require individual or smallemployer market insurers to include coverage of contraceptives in standardized plans offered to consumers. See 3 Colo Code Regs § 4-6-5 (West 2002); Ky Rev Stat Ann § 304.17A-250 (Michie 1996); 806 Ky Admin Reg \$ 17:180E (West 2001); NJ Admin Code $\$ 11: 20-3.1$ (West 2001).

60 For a discussion of laws without exemptions, see Part III. For a discussion of laws with exemptions, see Part IV. 


\section{A. Requirements of State Comprehensive Mandates}

Almost every state legislature has considered passing some form of contraceptive coverage law. ${ }^{61}$ Legislatures enacted these laws in response to research showing that virtually all large-group indemnity plans cover preventive prescription drugs yet do not cover all of the FDA-approved contraceptive drugs and devices. ${ }^{62}$ The failure to cover these methods affects women exclusively because there are no prescription contraceptive methods currently available for men. ${ }^{63}$ It is partly due to this exclusion that women of childbearing age pay approximately 68 percent higher out-of-pocket healthcare costs than do men. ${ }^{64}$ Women who cannot afford these additional costs may have considerable difficulty obtaining the most effective and appropriate contraceptives, resulting in an increase in unwanted pregnancies and in hazards to women's health. ${ }^{65}$ Contraceptive coverage laws are intended to eliminate discriminatory insurance practices that undermine the health and economic well-being of women. ${ }^{66}$ Part IV.B.1 will show

61 See generally The Contraception Report: A State-by-State Review of Access to Contraception (National Abortion and Reproductive Rights Action League ("NARAL") 2001), available online at <http:/www.naral.org/mediaresources/publications/2001cont> (visited Apr 29, 2002) (grading each state based on legislation providing access to contraceptives). There are also many laws pending before state legislatures. See NARAL's tracking database, available online at <http://mail.naral.org/longdoc.nsf> (visited Apr 29, 2002); Kaiser's tracking database, available online at <http://www.kaisernetwork.org/daily_reports/rep_repro.cfm> (visited Apr 29, 2002) (updated daily). Recently, a bill in the New York legislature passed both houses, and awaits the governor's signature. See NY AB 11723 (Feb 2, 2002), status available online at <http://assembly.state.ny.us/leg/?bn=a11723> (visited Apr 25, 2002).

Note, however, that all state contraceptive coverage laws do not apply to employers that selfinsure, and almost half of all employees work for companies that self-insure. See Susan A. Cohen, Federal Law Urged as Culmination of Contraceptive Insurance Coverage Campaign, in Guttmacher Report on Public Policy 10 (Oct 2001), available online at <http://www.guttmacher.org/pubs/journals/gr040510.pds (visited June 27, 2002).

62 See generally State Policies in Brief: Insurance Coverage of Contraceptives (Alan Guttmacher Institute 2001), available online at <http:/www.agi-usa.org/pubs/spib_ICC.pdf> (visited Feb 22, 2002); Uneven and Unequal: Insurance Coverage and Reproductive Health Services (Alan Guttmacher Institute 1994). For example, although prescription contraceptives are the most effective method of birth control, 49 percent of large-group indemnity plans do not include access to these methods. See id at *12-13.

63 See Catholic Charities of Sacramento, Inc v Superior Court of Sacramento County, 109 Cal Rptr 2d 176, 182 (App 2001); Testimony of Marcia D. Greenberger, Co-President, National Women's Law Center, before the Senate Committee on Health, Education, Labor, and Pensions, on Improving Women's Health: Why Contraceptive Coverage Matters, *20-22, ${ }^{*} 30-31$ (Sept 10, 2001), available online at <http://www.kaisernetwork.org/health_cast/uploaded_files/ ACF31C1.pdf $>$ (visited Feb 22, 2002).

64 See Catholic Charities, 109 Cal Rptr 2d at 182; Women's Health Insurance Costs and Experiences 2 (Women's Research and Education Institute 1994) (providing statistics on women's health care costs and insurance coverage).

65 See Catholic Charities, 109 Cal Rptr 2d at 182; Greenberger Testimony at *20-22, *30-31 (cited in note 63).

66 See, for example, Catholic Charities, 109 Cal Rptr 2d at 182-83 (discussing the legislative history and motivation for California's contraceptive coverage law). 
that this purpose is a compelling interest sufficient to override a free exercise claim.

In response to these concerns, nineteen states have enacted legislation or implemented regulations mandating that employers and/or insurers provide comprehensive contraceptive coverage. ${ }^{67}$ These comprehensive mandates require all private insurance companies to provide coverage of all FDA-approved prescription contraceptive benefits, including drugs, devices, and related medical services, if the insurer covers other prescription benefits. ${ }^{63}$ Only one of these states does not require coverage of related medical services. ${ }^{69}$ Congress is also considering a federal comprehensive mandate. ${ }^{70}$

Experts estimate that modifying an insurance plan to comply with the comprehensive mandate (assuming baseline coverage of no form of contraceptive benefits) would increase employers' overall insurance costs by only 0.6 percent. $^{7}$ Additionally, when taking cost sav-

67 See State Policies in Brief: Insurance Coverage at *1 (cited in note 62).

68 These states are Arizona, California, Connecticut, Delaware, Georgia, Hawaii, Iowa, Maine, Maryland, Massachusetts, Missouri, Nevada, New Hampshire, New Mexico, North Carolina, Rhode Island, Texas, Vermont, and Washington. See Ariz Rev Stat \$\$ 20-826, 20-1057.08, 201402, 20-1404, 20-2329 (2002), as amended by Arizona, $57 \mathrm{HB} 2234$ (signed into law Apr 21, 2002); Cal Health \& Safety Code $\$ 1367.25$ (West Supp 2001); 1999 Conn Acts 99-79, \$§ 1(e)-(f), 2(e)-(f) (Reg Sess); Conn Gen Stat Ann \$\$ 38a-503e, 38a-530e (West Supp 2001); 18 Del Code Ann § 3559 (Michie Supp 2000); Ga Code Ann §§ 33-24-59.6 (Lexis Supp 2001), 49-7-2, 49-7-6 (Michie 1998); Hawaii Rev Stat $\S \S 431: 10 A-116.6,431: 10 A-116.7,432: 1-604.5$ (Supp 2001); Iowa Code Ann $\$$ 514C.19 (West 2001); Iowa Admin Code $\$ 191-71.24$ (West 2001); 24-A Me Rev Stat Ann §§ 2756, 2847-G, 4247 (West 2001); Md Ins Code Ann § 15-826 (Supp 2001); Md Health-Gen Code Ann § 20-214 (2000); 175 Mass Gen Laws Ann § 47W (West 2002); Mo Ann Stat § 376.1199 (Vernon Supp 2002); Nev Rev Stat \$\$ 689A.0415, 689A.0417, 689B.0376, 689B.0377, 695C.1715, 695C.1717 (West 2001), NH Rev Stat Ann \$\$ 415:18-i, 420-A:17-c, 420-B:8-gg (Lexis Supp 2001); NM Stat Ann $\S \S 24-8-6,59 A-22-42,59 A-23-4,59 A-47-33$ (West 2001); NC Gen Stat § 58-3-178, 58-50-155 (Michie 1999); RI Gen Laws §§ 27-18-57, 27-19-48, 27-20-43, 27-41-59 (Supp 2001); Texas Ins Code Ann \$ 21.52L (Vernon 2001); 8 Vt Stat Ann § 4099c (1993); Wash Admin Code § 284-43-822 (2001). The Washington requirement is an agency rule, not a statute. See Wash Admin Code $\$ 284-43-822(2001)$.

69 See RI Gen Laws $\$ \S 27-18-57,27-19-48,27-20-43,27-41-59$ (Supp 2001) (covering all FDA-approved contraceptive drugs and devices but not services). Although none of these laws require coverage of abortion, some states (Rhode Island, Missouri, and North Carolina) specifically exclude drugs intended to induce an abortion. See RI Gen Laws \$\$ 27-18-57, 27-19-48, 2720-43, 27-41-59 (Supp 2001) (excluding RU 486); Mo Ann Stat § 376.1199 (Vernon Supp 2002) (excluding abortion-inducing drugs generally); NC Gen Stat \$ 58-3-178(e) (Michie 1999) (excluding Preven and RU 486).

70 See EPICC, HR 1111, 107th Cong, 1st Sess (Mar 20, 2001); S 104, 107th Cong, 1st Sess (Jan 22, 2001). See also note 2 and accompanying text.

71 See Rachel Benson Gold, The Need for and Cost of Mandating Private Insurance Coverage, in Guttmacher Report on Public Policy (1998), available online at $<$ http:/www.guttmacher.org/pubs/journals/gr010405.html> (visited Apr 29, 2002). If an employer that provided no form of contraceptive coverage modified its plan to provide coverage of the full range of reversible contraceptive methods, this would result in a total cost of $\$ 21.40$ per employee per year. Id. Assuming employers pay the standard 80 percent, employers would pay $\$ 17.12$, which translates into a monthly cost of $\$ 1.43$ per employee. Id. Employees would contribute $\$ 4.28$ per year, or $\$ 0.36$ per month. Id. 
ings into account, not providing coverage for the full range of contraceptive methods could cost an employer approximately 15-17 percent more than providing coverage. ${ }^{n}$ As minimal as these costs are, only employers providing insurance plans with no form of contraceptive coverage would bear the full 0.6 percent increase in cost. The cost would be significantly less for those employers that already cover some forms of contraception.

\section{B. Exemptions in Comprehensive Mandates}

States have enacted a variety of exemptions in contraceptive coverage laws. Some state laws have no religious exemptions. Additionally, some exemptions apply to employers, others to insurers, and some to both. ${ }^{3}$ Other exemptions only apply to a specific group of employers or insurers. Some exemptions apply to any religious employer or insurer that has religious beliefs against contraception and elects to invoke the exemption.

\section{No exemptions.}

Four states-Georgia, ${ }^{74}$ Iowa, ${ }^{75}$ New Hampshire, ${ }^{76}$ and Vermont ${ }^{7}-$ contain no conscience provisions, thereby requiring all insurers and employers to provide contraceptive coverage regardless of any individual insurer's or employer's religious beliefs. The proposed federal law also contains no exemptions. ${ }^{\text {T }}$ This Comment will show that, under Smith, these state laws do not violate the Free Exercise Clause.

72 See Rowena Bonoan and Juliana Gonen, Promoting Healthy Pregnancies: Counseling and Contraception as the First Step, Family Health in Brief 4-6 (Washington Business Group on Health 2000).

73 Although the laws' requirements operate on insurers (insurers must cover contraceptive benefits), the exemptions apply to both insurers (exempted insurers do not have to cover these benefits) and employers (an exempted employer may request that its insurer grant the employer an insurance policy that does not cover contraceptive benefits).

This Comment, however, is concerned solely with the constitutionality of distinctions between employers on the basis of type of organization ("selective exemptions") and not on the distinction between religious employers versus insurers. See Part II.B. This Comment does not address whether there is a constitutional problem with exempting either only employers or only insurers. Notably, however, all enacted selective exemptions apply only to employers. See Part II.B.3.

74 Ga Code Ann \$ 33-24-59.6 (Lexis Supp 2001).

75 Iowa Code Ann $\$$ 514C.19 (West 1998).

76 NH Rev Stat Ann $\S \S 415: 18-i, 420-A: 17-c, 420-B: 8-g g$ (Lexis Supp 2001).

778 Vt Stat Ann § 4099c (1993).

78 See EPICC, HR 1111, 107th Cong, 1st Sess (Mar 20, 2001); S 104, 107th Cong, 1st Sess (Jan 22,2001). The constitutionality of EPICC depends on whether the RFRA is constitutional as applied to federal laws. See note 48. If RFRA is found unconstitutional, then EPICC is analyzed under the framework of this Comment: As a law with no exemptions, it is generally applicable and neutral under Smith and therefore constitutional. If RFRA does apply, then EPICC must pass strict scrutiny. This Comment argues that all contraceptive coverage laws fulfill the 


\section{Broad exemptions.}

Six states do not define the exempted group, allowing an organization itself to decide whether it is "religious" and therefore within the scope of the exemption. Some exempt insurers and others exempt employers. Delaware's ${ }^{\text {so }}$ and Maryland's statutes contain conscience provisions that exempt a religious employer when covering contraceptives would conflict with the organization's "bona fide religious beliefs and practices." Nevada exempts an insurer "affiliated with a religious organization" if it objects to coverage "on religious grounds," Texas exempts an insurer "associated with a religious organization" if it "violates the religious convictions of the organization."

Missouri, the only state to allow employers that are not religious entities to opt out, exempts an "entity purchasing" coverage (meaning an employer), if it is "contrary to the moral, ethical, or religious beliefs or tenets" of the entity. New Mexico provides a blanket exemption to "religious" employers without explicitly requiring that contraception be against the employer's religious beliefs.

Laws with broad exemptions do not violate the free exercise rights of any religious employer or insurer because they allow the entity to self-identify as eligible for the exemption. To qualify for the exemption under a law with a broad exemption, an entity simply needs to state that it is a religious organization and that it has a belief against the use of contraception. No religious organization would have standing to bring a free exercise challenge. However, a law with a broad exemption could be challenged as violating the Fourteenth Amendment's Equal Protection Clause, the First Amendment's Establishment Clause, or an individual employee's rights under the Free Exercise Clause. ${ }^{\text {. }}$ All of these challenges are outside the scope of this

compelling interest of ending gender discrimination in insurance practices. See Part IV.B.1. However, this Comment focuses exclusively on whether the laws' exemptions are narrowly tailored to fulfill this interest. See Part IV.B.2. Because EPICC has no exemptions, the requirements of the law would have to be narrowly tailored to fulfill the interest. This inquiry, beyond the scope of this Comment, entails examining the specific mandates of EPICC as they relate to the goal of eradicating gender discrimination in insurance benefits.

79 See Part III.

sa 18 Del Code Ann $\$ 3559$ (Michie Supp 2000).

81 Md Ins Code Ann \$ 15-826(c) (Supp 2001).

82 Nev Rev Stat §§ 689A.0415(5), 689A.0417(5), 689B.0377(5) (West 2001).

83 Texas Ins Code Ann \$ 21.52L (Vernon 2001).

84 Mo Ann Stat $\$ 376.1199$ (Vernon Supp 2002). Missouri also exempts an insurer "owned, operated or controlled in substantial part by an entity that is operated pursuant to moral, ethical or religious tenets that are contrary to the use or provision of contraceptives." Id. For free exercise purposes, the insurer exemption would be categorized as a selective exemption.

85 NM Stat Ann $\$ \S 24-8-6,59 A-22-42,59 A-23-4,59 A-47-33$ (West 2001).

86 An equal protection challenge could be brought by female employees whose employers opt out under the exemption; an Establishment Clause challenge would be brought by employers and insurers that (1) are either not religious and therefore do not qualify for the exemption 
Comment, which focuses exclusively on the free exercise rights of religious employers and insurers.

\section{Selective exemptions.}

Some exemptions distinguish among religious organizations based on the type of organization. For example, a law may exempt a church but not a school operated by a church. These laws with selective exemptions may infringe on the free exercise rights of religious employers and insurers that fall outside the scope of the exemption because the laws force these entities to provide contraceptives, thereby forcing them to violate their religious tenets."

Nine states exempt religious employers when providing contraception is against the entity's religious beliefs, but these states add a detailed definition of which employers qualify for the exemption. These selective exemptions can be divided into three categories. First, four states provide that only "churches" as defined by Section 3121(w) of the Internal Revenue Code qualify for the exemptions ("Section 3121 exemptions"). ${ }^{38}$ Rhode Island ${ }^{\text {s9 }}$ and Massachusetts ${ }^{90}$ define a religious employer as a "church or a qualified church-controlled organization" as defined by Section 3121(w). Section 3121(w) defines a "church" as including the equivalent of churches in other religions, such as temples, mosques, and synagogues." Connecticut's ${ }^{\text {s2 }}$ and

or (2) are religious but do not fall within the exemption's scope; an individual free exercise claim would be brought by employees (employed by an entity not exempted) who do not believe in the use of contraception and are required to subsidize the contraceptive benefits of other employees through insurance premiums. See note 71 .

87 Regardless of the concern that the law may be "establishing" the exempted religion, the law forces the nonexempted employer to perform and that directly violates its religious beliefs. Laws that force individuals or entities to violate their religious beliefs pose a free exercise concern. As noted in the introduction, these concerns are outside the scope of this Comment.

8826 USC $\$ 3121$ (w) (1994).

89 RI Gen Laws $\$ \S 27-18-57,27-19-48,27-20-43,27-41-59$ (Supp 2001) (exempting "religious employers" if coverage is "contrary to the religious employer's bona fide religious tenets" and defining an eligible employer as a "church or a qualified church-controlled organization' as defined in 26 USC 3121 ").

90 See 175 Mass Gen Laws Ann § 47W (West 2002) (exempting an employer that is a "church or qualified church-controlled organization" as defined by 26 USC $\S 3121(\mathrm{w})(3)(\mathrm{A}),(\mathrm{B}))$.

91 See 26 USC $\$ 3121(w)$ (1994).

921999 Conn Acts 99-79, §§ 1(e)-(f), 2(e)-(f) (Reg Sess) (exempting entities "owned, operated or substantially controlled by a religious organization" if coverage is contrary to the entity's "religious or moral tenets" and defining such an employer as "a 'qualified churchcontrolled organization' as defined in 26 USC $\$ 3121$ or a church-affiliated organization") (emphasis added). Although Connecticut law does not exempt insurers, it allows a religious insurer to provide for the coverage of contraceptives though a subcontractor. Eligible insurers are defined as "any insurance company, hospital or medical service corporation, or health care center which is owned, operated or substantially controlled by a religious organization which has religious or moral tenets which conflict" with contraceptive coverage. This insurer "carve-out" 
Maine's ${ }^{93}$ definitions add further requirements beyond Section 3121(w)'s definition.

Second, four states have crafted their exemptions by focusing on the purpose of an organization and the people involved in it ("purpose/membership exemptions"). North Carolina exempts religious employers that (1) are organized and operated for religious purposes, (2) are tax exempt under 26 USC $\$ 501,{ }^{*}$ (3) have the purpose of inculcating religious values, and (4) primarily employ persons who share its religious tenets. ${ }^{95}$ Hawaii removes the organizational requirement and adds a requirement that the entity not be staffed by public employees. ${ }^{\text {\% }}$ California modifies the North Carolina exemption in two ways. First, it requires tax exempt status under a different section of the Internal Revenue Code, 26 USC $\S 6033 ;^{97}$ second, it replaces the religious organization requirement with a requirement that the organization primarily serve persons who share its religious tenets. ${ }^{93}$ Arizona also requires tax exempt status under Section 6033. Addition-

would be treated like a selective exemption.

$9324 \mathrm{Me}$ Rev Stat Ann $\S$ 2756(2), 2847-G(2), 4247(2) (West 2000) (exempting "religious employers" if coverage "conflicts with the religious employer's bona fide religious beliefs and practices" and defining an eligible employer as "an employer that is a church, convention or association of churches or an elementary or secondary school that is controlled, operated or principally supported by a church or by a convention or association of churches" as defined by 26 USC $\$ 3121$ and that is tax-exempt under 26 USC $\$ 501$ (c)(3)).

9426 USC $\$ 501$ (1994).

95 NC Gen Stat $\$ 58-3-178(e)$ (West 2001) exempts "religious employers" if coverage is "contrary to the employer's religious tenets" and defines an eligible employer as follows:

[An eligible employer is] an entity for which all of the following are true: (1) the entity is organized and operated for religious purposes and is tax exempt under [26 USC $\$ 501(c)(3)]$. (2) The inculcation of religious values is one of the primary purposes of the entity. (3) The entity employs primarily persons who share the religious tenets of the entity.

96 Hawaii Rev Stat Ann § 431:10A-116.7 (1993 \& Supp 2000) defines an exempted entity as follows:

[An exempted entity is] an entity for which each of the following is true: (1) the inculcation of religious values is the purpose of the entity; (2) the entity primarily employs persons who share the religious tenets of the entity; (3) the entity is not staffed by public employees; and (4) the entity is a nonprofit organization [under 26 USC \$ 501(c)(3)]).

The Hawaii law specifies that "any educational, health care, or other non-profit institution or organization owned or controlled by the religious employer is included in this exemption." Id. The law also provides that employees affected by employer exemptions may purchase contraceptive coverage on their own at the same price as the group rate would have been. Id.

9726 USC $\$ 6033$ (1994).

93 Cal Health \& Safety Code $\$ 1367.25$ (b) defines an exempted entity as follows:

[An exempted entity is] an entity for which each of the following is true: (A) The inculcation of religious values is the purpose of the entity. (B) The entity primarily employs persons who share the religious tenets of the entity. (C) The entity serves primarily persons who share the religious tenets of the entity. (D) The entity is a non-profit organization [under 26 USC $\$ 6033(a)(2)(A)$ (i) or (iii)].

99 Ariz Rev Stat $\$ 20-826,20-1057.08(F)$ defines an exempted organization as follows: An exempt entity is "an entity for which all of the following apply: (1) the entity primarily employs 
ally, Arizona drops North Carolina's "organized and operated" prong. ${ }^{100}$

Finally, Washington State's exemption is unique in that it incorporates by reference a previously-enacted exemption. ${ }^{101}$ This exemption, however, only applies to a very limited segment of the insurer market. ${ }^{102}$ In sum, the free exercise analysis of state contraceptive coverage laws depends on whether the law includes no exemption, a broad exemption, or a selective exemption. Broad exemptions do not pose a free exercise problem because they exempt any religious entity that chooses to self-define as a religious entity. Part III will show that laws with no exemptions comport with the Free Exercise Clause under the Smith test. Part IV will argue that laws with selective exemptions fail Smith and therefore must survive strict scrutiny to be constitutional.

\section{STATE LAWS WITHOUT EXEMPTIONS ARE CONSTITUTIONAL UNDER THE FREE EXERCISE CLAUSE}

State laws without exemptions are constitutional because they are (1) neutral and (2) generally applicable under Smith..$^{103}$ The laws are neutral because they are not targeted at suppressing religion, but instead aim to end gender discrimination in insurance practices. They are generally applicable because they apply to all employers and/or insurers, exempting no entities.

First, a law's neutrality is determined by the text and the purpose of the law. ${ }^{104}$ The texts of these laws are silent on religion. ${ }^{105}$ As de-

persons who share the religious tenets of the entity, (2) the entity serves primarily persons who share the religious tenets of the entity, (3) the entity is a nonprofit organization as described in Section 6033(a)(2)(A)i or iii [of 26 USC]."

100 Id. See also note 95.

101 Wash Rev Code Ann $\S 48.43 .065$ (2)(a) (West 1999) ("No individual health care provider, religiously sponsored health carrier, or health care facility may be required by law ... in any circumstances to participate in the provision of or payment for a specific service if they object to so doing for reason of conscience or religion."). Washington, however, protects employees' rights to "timely access" to excluded services. Id.

102 See id at $\$ 48.43 .065$ (1) (exempting only insurers related to a state-defined "basic health plan" or its equivalent). This Comment does not analyze the Washington exemption because the exemption raises issues as to whether certain segments of the health care market can constitutionally be singled out.

103 Preliminarily, in order for a valid free exercise claim to exist, the contraceptive coverage laws must actually burden an entity's sincerely held religious belief or practice. See Sherbert, 374 US at 403-04 ("We turn first to the question whether the [law] impose[s] any burden on the free exercise of appellant's religion."); United States $y$ Ballard, 322 US 78, 86-88 (1944) (noting that a belief must be sincerely held but need not be a true belief). Here, religious organizations that believe that facilitating the use of contraception is a sin and therefore do not want to commit the sin of facilitation are burdened by laws that force them to include contraceptive coverage in health plans offered to their employees thereby forcing them to commit a sin. See Catholic Charities of Sacramento, Inc $v$ Superior Court of Sacramento County, 109 Cal Rptr 2d 176, 184 (App 2001).

104 Lukumi, 508 US at 533-42. 
scribed in Part II.A, legislatures enacted contraceptive coverage laws to decrease the financial burden on women purchasing birth control, thereby eliminating gender discrimination in prescription drug benefits. ${ }^{136}$ Unlike the city council in Lukumi, ${ }^{107}$ legislators were not primarily concerned with suppressing a religious practice. ${ }^{103}$

Additionally, even if a law substantially burdens religion, that law is still neutral if the law's purpose is not to suppress religious exercise and the resulting burden is merely incidental. ${ }^{109}$ For example, a law that prohibited landlords from discriminating against tenants on the basis of marital status was held to be neutral because it only "incidentally burdened" the landlord's religious freedom by forcing him to facilitate what he considered the sin of premarital cohabitation. ${ }^{10}$ Courts also have held zoning ordinances to be neutral on the same rationale, although such ordinances may force churches to relocate ${ }^{\mathrm{mI}}$ or the ordinances may injure the churches financially. ${ }^{12}$ Similarly, any burden on a religious employer resulting from a contraceptive law is an incidental effect of the legislation, not its primary effect or purpose.

Second, these contraceptive coverage laws do not exempt any employers, insurers, or other parties. Therefore, these law apply to all entities and are generally applicable. Contrast these laws with the ordinances in Lukumi that specifically prohibited religious killings but allowed nonreligious ones. ${ }^{1.3}$ Unlike the ordinances in Lukumi, an ordinance requiring that all door-to-door solicitors apply for a permit without exempting religious organizations was held to be generally applicable because it required all individuals to register irrespective of the content of their messages. ${ }^{14}$ Similarly, contraceptive coverage laws

105 See, for example, Ga Code Ann § 33-24-59.6 (containing no language about employers or insurers objecting on the basis of religious belief).

106 See, for example, Washington Rulemaking Order, Wash Admin Code § 284-43-822 (2001) ("It is unfair practice for any health carrier to restrict, exclude, or reduce coverage or benefits under any health plan on the basis of sex.").

107508 US at 542.

108 Except where there is evidence of specific egregious intent, as apparently existed in $\mathrm{Lu}$ $k u m i$, it will be difficult to find malicious persecution of religion as a motivation for the laws.

109 See Smith, 494 US at 878-79.

110 See Thomas v Anchorage Equal Rights Commission, 165 F3d 692, 702 (9th Cir 1999) (holding a law that prohibited landlords from discriminating against tenants on the basis of marital status to be neutral), withdrawn on other grounds, 192 F3d 1208 (9th Cir 1999).

111 See, for example, Mount Elliot Cemetery Association v City of Troy, 171 F3d 398, 405 (6th Cir 1999) (finding no religious exemption to a zoning ordinance that had the effect of prohibiting the construction of a Catholic cemetery).

112 See, for example, Rector of St. Bartholomew's Church $v$ City of New York, 914 F2d 348, 354-55 (2d Cir 1990) (finding no religious exemption to a landmark ordinance that restricted the Church's ability to raise revenue).

113 See 508 US at 543.

114 See Watchtower Bible and Tract Society of New York, Inc $v$ Village of Stratton, 240 F3d $553,568-69$ (6th Cir 2001). 
without exemptions require both religious and nonreligious employers and insurers to provide contraceptive coverage; they do not single out any organizations. Although it may seem counterintuitive, contraceptive coverage laws with no accommodations for religious employers or insurers do not violate the Free Exercise Clause test created by Smith.

\section{ENACTED STATE LAWS WITH SELECTIVE EXEMPTIONS ARE CONSTITUTIONAL}

This Part proposes a framework for courts to use when assessing the constitutionality of contraceptive coverage laws with selective exemptions. These laws exempt only a certain subset of religious employers, with the sets defined either by Section 3121 of the Internal Revenue Code or by the purpose and membership of the organization. Part $\mathrm{A}$ argues that all laws with exemptions are not generally applicable precisely because they have exemptions. These laws fail the Smith test and thus, must pass strict scrutiny in order to be constitutional. Part B then argues that laws with selective exemptions survive strict scrutiny because they fulfill the compelling state interest of eradicating gender discrimination and are narrowly tailored to achieve this objective.

\section{A. State Laws with Exemptions Are Not Generally Applicable under Smith}

This Part will show that laws that contain exemptions are, by definition, not generally applicable because they do not apply to every entity or every person. These laws, therefore, should fail the Smith test. ${ }^{\text {1is }}$ The Supreme Court has not explicitly stated this, but such a conclusion should be drawn from both the plain meaning of the term "general applicability" - a law that does not apply to everyone is not generally applicable-and Smith's concerns regarding possible discrimination against religion.

In Smith, the Court specifically held that laws with exemptions fail the Smith test, although it did not state that this failure was based on the general applicability prong. ${ }^{116}$ Smith notes that laws with a "system of individualized exemptions" fail the Smith test." When distinguishing systems of individual exemptions from generally applicable

115 See Lukumi, 508 US at 537 ("[I]n circumstances in which individualized exemptions from a general requirement are available, the government may not refuse to extend that system to cases of religious hardship without compelling reasons.") (citation and quotations omitted).

116 See Smith, 494 US at 883-84 (noting that the Court applied strict scrutiny in previous free exercise cases because those laws contained exemptions, whereas the law at issue in Smith did not), discussing Sherbert, 374 US at 401; Bowen v Roy, 476 US 693, 708 (1986); Thomas v Review Board of Indiana Employment Security Division, 450 US 707 (1981).

117 Smith, 494 US at 884. 
laws, the Court in Smith and Lukumi was concerned with the government's ability to assess who is exempt and who must comply with the law, noting that such a decision is discretionary and therefore could be influenced by possible government hostility toward religion. ${ }^{118}$ For example, the government may grant exemptions for individuals requesting exemptions on the basis of secular reasons but not for those individuals requesting them for religious reasons. Due to this concern, the Court requires that such laws survive the more rigorous test of strict scrutiny." Smith pointed to laws with exemptions for "good cause" as examples of individualized exemptions. ${ }^{120}$

Selective exemptions in contraceptive coverage laws, albeit not as discretionary as an exemption for good cause, raise the same concerns about discriminatory intent. For instance, the government must decide whether an organization is a "church or qualified church-controlled" and therefore qualifies under the Section 3121 standard. ${ }^{121}$ Similarly, the government must assess whether an organization's purpose is "the inculcation of religious values" and therefore qualifies under California's modified purpose/membership standard. ${ }^{12}$ Determining an organization's purpose involves discretion and a state could manipulate such a determination out of a bias against certain religions. For example, an organization could have dual purposes of inculcating Catholic values and ending world hunger. California could determine that the purpose of the organization is to end world hunger specifically because the state is motivated by anti-Catholic sentiment and does not want to exempt the organization from providing contraceptive coverage to its employees. If laws with selective exemptions were held to be generally applicable, states could draw arbitrary distinctions regarding which entities to exempt without having to justify the distinction at all. ${ }^{123}$ Thus, all exemptions should be considered "individualized" because they involve the dangers inherent in discretion that concerned the Supreme Court. ${ }^{22}$

118 See id ("The Sherbert test ... was developed in a context that lent itself to individualized government assessment of the reasons for relevant conduct. . . . [A] distinctive feature of [such exemptions] is that their eligibility criteria invite consideration of the particular circumstances [of] an applicant]."); Lukumi, 508 US at 542 ("All laws are selective to some extent, but categories of selection are of paramount concern when a law has the incidental effect of burdening religious practice."). See also Bowen, 476 US at 708 (reasoning that the government's "refusal to extend an exemption to an instance of religious hardship suggests a discriminatory intent").

119 See Lukumi, 508 US at 542; Smith, 494 US at 884.

120 See Smith, 494 US at 884, discussing Sherbert, 374 US at 401, and Thomas, 450 US at 707.

121 See notes $88-93$.

122 See note 98 .

123 Selective exemptions may even make the laws not "neutral," causing the laws to fail the second prong of the Smith test as well because they discriminate between religious entities on the basis of religious practice. See Part IV.B.2.

124 See Fraternal Order of Police Newark Lodge No 12 v City of Newark, 170 F3d 359, 365 
The Court's failure to explain the meaning of an "individualized" exemption and how it affects the general applicability of a law has caused much confusion in free exercise jurisprudence. Lower courts have come to differing conclusions as to the correct definition. The Third Circuit, in Fraternal Order of Police Newark Lodge No $12 v$ City of Newark, ${ }^{125}$ held that a law with an exemption was not generally applicable and therefore failed the Smith test. ${ }^{126}$ In Fraternal Order of Police, the Newark Police Department refused to grant an exemption to Sunni Muslim officers from a policy requiring that all male police offices shave their facial hair despite the officers belief that failing to wear a beard was a religious sin. ${ }^{127}$ The policy, however, contained a medical exemption for officers who had a particular skin condition. ${ }^{12}$ The court held that this policy failed the Smith test and was therefore subject to strict scrutiny specifically because the law contained an exemption. ${ }^{129}$ The court reasoned that there should be no legal distinction between an individualized exemption for good cause and a "categorical exemption" for a skin condition because the reasoning underlying the application of strict scrutiny for "individualized exemptions" in Smith and Lukumi applies to categorical exceptions as well. ${ }^{130} \mathrm{~A}$ federal district court in Maryland reached a similar conclusion. ${ }^{131}$ Selective exemptions in contraceptive coverage laws are exactly this type of

(3d Cir 1999).

125 170 F3d 359 (3d Cir 1999).

126 Id at 365.

127 See id at $360-61$.

128 See id at 360 (explaining the exemption for "pseudo folliculitis barbae").

129 See id at 365-66.

130

While the Supreme Court did speak in terms of 'individualized exemptions' in Smith and Lukumi, it is clear from those decisions that the Court's concern was the prospect of the government's, deciding [which] motivations are more important. ... If anything, this concern is only further implicated when the government does not merely create a mechanism for individualized exemptions, but instead creates a categorical exemption for individuals with a secular objection but not for individuals with a religious objection.

Id, citing Lukumi, 508 US at 542, and Smith, 494 US 872. See also analysis in text accompanying notes 116-123. Although the court was concerned with the government choosing secular reasons over religious reasons when determining whether an individual falls into the scope of an exemption (secular $\mathrm{v}$ religion), the same concern of possible discrimination against religion is present when the government grants an exemption for one religious reason but not another religious reason (religion v religion). Contraceptive coverage laws with selective exemptions implicate this latter concern.

131 See Keeler v Mayor and City Council of Cumberland, 940 F Supp 879, 885-86 (D Md 1996) (holding that a law requiring the preservation of historic buildings, with exemptions in cases where retaining a building would deter a major improvement program, cause the owner undue financial hardship, or not be in the best interest of the community, was a "system of individualized exemptions" and therefore failed the Smith test because the government scheme preferred those reasons for exemption over others-for example, religious reasons) (emphasis added). 
"categorical exemption" that the Third Circuit recognized can implicate the Supreme Court's concerns of the dangers of discretion.

Three lower courts have reached a conclusion opposite to that of the Third Circuit. The California Court of Appeals for the Third District, the only court to assess a contraceptive coverage law's constitutionality, concluded that that the California law was generally applicable although it had a selective exemption. ${ }^{132}$ The California court's analysis focused only on the motivation of the legislature, thereby combining neutrality and general applicability. ${ }^{1.3}$ The court held that the "exemption is neutral and generally applicable to all religions. It does not discriminate among religions, but applies to all faiths in the same manner, exempting some but not all parts of all religious organizations." gious entities instead of on whether the law applies to all entities, including both religious and nonreligious ones. In both Smith and $\mathrm{Lu}$ kumi, the Court focused on whether the laws at issue applied to all individuals or organizations. ${ }^{135}$ This reading does not comport with Smith because general applicability means that the law applies to everyone equally, not just to religions equally. ${ }^{136}$

The California appellate court relied on an Eleventh Circuit decision, First Assembly of God $v$ Collier County, Florida. ${ }^{137}$ In First Assembly, a church challenged a zoning ordinance that limited the use of the land for residential purposes but exempted religious "customary uses." ${ }^{123}$ The court engaged in no analysis of the general applicability prong, merely stating that the ordinance "zones an entire residential area and makes a special exception for churches. It is neutral on its face and is of general applicability." ${ }^{139}$ The court never explained how a law with an explicit exemption could possibly apply to all landowners, and therefore be considered generally applicable. ${ }^{140}$ Similarly, the Ninth Circuit held that "exemptions exclud[ing] entire, objectivelydefined categories ... are not 'individualized exemptions' within the meaning of Smith," yet did not explain why this must be the case. ${ }^{1.1}$

132 See Catholic Charities of Sacramento, Inc v Superior Court of Sacramento Country, 109

Cal Rptr 2d 176 (App 2001). See also notes 8-9 and accompanying text.

133 Catholic Charities, 109 Cal Rptr 2d at 187-93.

134 See id at 189.

135 See Smith, 494 US at 884 (noting that the law at issue was "an across-the-board" drug prohibition); Lukumi, 508 US at 546 (explaining that the ordinance at issue was subject to strict scrutiny because it did not apply to all entities, both religious and nonreligious).

136 See notes $115-31$ and accompanying text.

13720 F3d 419 (11th Cir 1994).

138 Id at 420 .

139 Id at 423.

140 See id.

141 See American Friends Service Committee Corp v Thornburgh, 961 F2d 1405, 1408-09 (9th Cir 1991) (holding a law generally applicable despite the existence of exemptions for "inde- 
These three courts have misunderstood the Smith test. As explained above, the Supreme Court's rationale for requiring that highly discretionary exemptions for good cause survive strict scrutiny applies just as forcefully to exemptions for categories because government hostility to religion could be present in a determination of who qualifies for any exemption. ${ }^{142}$ Additionally, the plain meaning of the term general applicability requires that a law applies to all individuals or entities; a law with an exemption by definition does not apply to all. Thus, under a correct reading of Smith, contraceptive coverage laws with exemptions should fail the Smith test simply because they contain exemptions. ${ }^{143}$

\section{B. Enacted State Laws with Selective Exemptions Are Constitutional under the Strict Scrutiny Test}

Because contraceptive coverage laws fail the Smith test, they must survive strict scrutiny-they must be narrowly tailored to serve a compelling state interest. Because these laws include statutory exemptions, the exemptions themselves are subject to this analysis. ${ }^{144}$ Part IV.B.1 argues that contraceptive coverage laws and selective exemptions serve the compelling government interest of eradicating gender discrimination. Part IV.B.2 argues that all selective exemptions are narrowly tailored because they either exempt a Supreme Courtapproved category and are therefore "presumptively narrowly tailored" or draw distinctions among religious organizations that specifically relate to the compelling interest.

1. Contraceptive coverage laws serve the compelling interest of ending gender discrimination.

To survive strict scrutiny, a law must serve a compelling state interest. More specifically, in the case of a statutory exemption, a state may not refuse to extend that exemption without a compelling reason. ${ }^{145}$ This inquiry concerns the interest justifying the exemption of certain religious organizations but not others. ${ }^{145}$ The Court has not

pendent contractors, household employees and employees hired prior to November, 1986").

142 See text accompanying notes 122-31, 133-39.

143 This conclusion does not necessarily mandate that legislatures can never pass statutory exemptions. Legislative exemptions will be constitutional if they are either (1) broad exemptions, exempting any religious entity that chooses to self-define, see text accompanying notes $80-86$, or (2) selective exemptions that pass strict scrutiny.

144 See Lukumi, 508 at 537, quoting Smith, 494 US at 884; Smith, 494 US at 884 ("The government cannot refuse to extend [the exemption] to cases of religious hardship without compelling reasons."), citing Bowen v Roy, 476 US 693, 708 (1986). See also text accompanying notes $32-33$.

145 See notes 29-32.

146 Although it may seem initially that differentiating between religious denominations in- 
provided clear guidance on what constitutes a compelling interest; ${ }^{147}$ thus, it is difficult to determine whether an interest is compelling. First, this Part demonstrates that contraceptive coverage laws and selective exemptions were designed to eradicate gender discrimination. Next, it shows that this government interest is compelling. Last, it shows that the reason for failing to extend the exemption is also grounded in the goal of eliminating gender discrimination.

Lukumi determined the purpose of the ordinances at issue based on the text of the law and the circumstances surrounding its enactment. ${ }^{1 / 4}$ As explained in Part II.A, all contraceptive coverage laws were designed to eliminate gender discrimination in insurance, which harms women's health and places extra financial burdens on women. ${ }^{14}$ The text of the Washington regulation, for example, states that its purpose is to eliminate gender discrimination in prescription drug benefits. "The legislative history of the California law discloses that the law was enacted to eliminate discriminatory insurance practices that had undermined the health and economic well-being of women. ${ }^{151}$ Similarly, sponsors of the Maryland legislation stated that its purpose was to promote gender equity by requiring insurers and employers to treat women's contraceptive drugs and devices the same as other prescriptions. ${ }^{152}$

States enacted contraceptive coverage laws with selective exemptions rather than laws with no exemptions as a compromise between the two competing concerns that (1) allowing too many entities to opt

vokes only an Establishment Clause concern, this Comment reveals that such unequal treatment also prevents a potential a free exercise claim that has been largely ignored by courts. See Board of Education, Kiryas Joel Village School District v Grumet, 512 US 687, 696 (1984) (“'A proper respect for both the Free Exercise and the Establishment Clauses compels the State to pursue a course of "neutrality" toward religion,' favoring neither one religion over others."), quoting Committee for Public Education \& Religious Liberty v Nyquist, 413 US 756, 792-93 (1973); Larson $v$ Valente, 456 US 228, 245 (1982) ("[The] constitutional prohibition of denominational preference is inextricably connected with the ... Free Exercise Clause."). When a state forces an organization to comply with a law that violates its religious beliefs, the state infringes on that organization's right to free exercise of religion.

147 See notes $32-37$ and accompanying text.

145 See 508 US at $540-42$ (determining that the animal cruelty ordinances were intended to suppress the Santeria's religious practice based on the text and clear legislative motivation). Assessing the purpose of every state statute is beyond the scope of this Comment, and this Part will therefore use selected states as examples.

149 See The Contraception Report (cited in note 61) (providing a broad overview of state contraception coverage laws and their justifications).

150 See Washington Rulemaking Order, Wash Admin Code $\$ 284-43-822$ (2001). See also note 106.

151 See Catholic Charities of Sacramento, Inc v Superior Court of Sacramento County, 109 Cal Rptr 2d 176, 182-83 (App 2001) (extensively examining the legislative history and purpose behind the California law). See also notes 62-66 and accompanying text.

152 See Michael Dresser, Birth Control Coverage Law Urged:Advocates of Family Planning Testify, Balt Sun 1B (Feb 20,1998) (discussing the views of various Maryland state delegates). 
out (by enacting a broad exemption) would perpetuate gender discriminatory practices and (2) allowing no entities to opt out (by enacting no exemption) would force all entities with religious beliefs against the use of contraception to engage in an act that they consider to be a $\sin ^{153}$ Selective exemptions prevent more gender discrimination against female employees. Thus, the compelling reason for failing to expand the scope of the exemptions is to eradicate as much gender discrimination in insurance plans as possible while allowing religious entities some religious liberty.

Second, the Court has held that eradicating discrimination against women is a compelling interest sufficient to justify restrictions on First Amendment rights, albeit in the context of the right to freedom of association. ${ }^{154}$ In particular, discrimination on the basis of a woman's ability to become pregnant constitutes gender discrimination under the Pregnancy Discrimination Act ("PDA"), part of Title VII. ${ }^{1.5}$ Thus, the PDA serves a compelling interest. ${ }^{156}$ Only one district court and the Equal Employment Opportunity Commission ("EEOC") have addressed this issue, and both held that failing to provide contraceptive coverage, even in the absence of a contraceptive coverage law requiring such provision, violates the PDA. ${ }^{157}$ The EEOC held that,

153 See The Contraception Report at *ii, *xiii-xv (cited in note 61); Women's Health Insurance Costs and Experiences at 3 (cited in note 64).

154 See Roberts $v$ United States Jaycees, 468 US 609, 623 (1984) (holding that the state's compelling interest in ending gender discrimination justified infringement on the all-male Jaycees' right to freedom of association). Boy Scouts of America v Dale, 530 US 640 (2000), does not affect the validity of Roberts's holding concerning discrimination against women, because Dale involved discrimination against homosexuals.

155 See Title VII of the Civil Rights Act, as amended by the PDA, 42 USC $\$ 2000$ e(k) (1994) (prohibiting discrimination against women "affected by pregnancy, childbirth, or related medical conditions"); International Union, UAW v Johnson Controls, Inc, 499 US 187, 199 (1991) ("The [PDA] has now made clear that ... discrimination based on a woman's pregnancy is, on its face, discrimination because of her sex.") (citation omitted). See also California Federal Savings \& Loan Association v Guerra, 479 US 272, 277 (1987) ("The PDA specifies that sex discrimination includes discrimination on the basis of pregnancy.").

156 This Comment does not argue that a statutory right under the PDA trumps a constitutional free exercise right. Instead, it argues that because ending discrimination on the basis of the ability to become pregnant is "gender discrimination" for Title VII purposes, it should be considered gender discrimination for other purposes as well. Before the PDA was enacted, however, the Court held that discrimination on the basis of pregnancy was not gender discrimination under the Equal Protection Clause. See General Electric Co v Gilbert, 429 US 125, 144-45 (1976). See generally Geduldig v Aiello, 417 US 484 (1974). However, commentators suggest that Geduldig might be decided differently today. See, for example, Catharine A. MacKinnon, Sex Equality 247-77, 385-428, 1201-1394 (Foundation 2001). Additionally, even if it is not considered discrimination for purposes of equal protection, a court should still consider it a sufficiently compelling state interest to override a free exercise claim.

157 See Erickson v The Bartell Drug Co, 141 F Supp 2d 1266, 1271 (W D Wash 2001); Equal Employment Opportunity Commission Decision (EEOC Dec 14, 2000), available online at $<$ http://www.eeoc.gov/docs/decision-contraception.html> (visited Feb 22, 2002) (“EEOC Decision"). Notably, Title VII does not include any relevant exemptions. See Title VII, 42 USC $\S 2000$ e (1994). Relying solely on Title VII for access to contraceptives is not as protective of 
under the PDA, if employers subsidize a wide range of other products and services designed to prevent illness or enhance well-being, then they must also subsidize contraceptives. ${ }^{15}$ The EEOC reasoned that contraception is a means by which a woman controls her ability to become pregnant, and this ability is protected under the PDA. ${ }^{159} \mathrm{~A}$ Washington federal district court reached the same conclusion. ${ }^{160}$

The remaining question is whether the state interest of eradicating gender discrimination is "compelling" when weighed against the right to practice one's religion freely. The Supreme Court has held that the government's interest in ending racial discrimination is a sufficiently compelling interest to outweigh the right to free exercise of religion. ${ }^{161}$ Courts have also allowed religious liberties to be limited by interests that border on governmental convenience or efficiency, such as preventing fraud and assuring participation in tax systems. ${ }^{162}$ Surely

women's rights because Title VII only applies to employers with more than fourteen employees. See id at $\$ 2000$ e(b) (1994) (defining "employer"). Fewer than one fifth of employers are therefore protected under Title VII, leaving out fourteen million people working for small businesses and sixteen million who obtain health insurance through the individual market. See Cohen, Federal Law Urged at 10-11 (cited in note 61). Thus, relying solely on the PDA and Title VII to require employers to provide contraceptive coverage would leave millions of female employees without contraceptive benefits. The passage of EPICC, however, would ensure that all female employees receive these needed benefits. See notes 2,70 and accompanying text.

158 See EEOC Decision (cited in note 157) (considering a discrimination charge by two nurses). See generally Sylvia A. Law, Sex Discrimination and Insurance for Contraception, 73 Wash L Rev 363 (1998) (arguing that the PDA requires contraceptive coverage). Although EEOC decisions are nonprecedential for courts, other courts may still look to the decision for guidance.

159 See $E \dot{E} O C$ Decision (cited in note 157).

160 See Erickson, $141 \mathrm{~F}$ Supp 2d at 1271 (reasoning that, because only women are subject to pregnancy, "[t]he special or increased healthcare needs associated with a woman's unique sexbased characteristics must be met to the same extent, and on the same term, as other healthcare needs").

Two similar cases are pending before district courts. In July 2001, employees brought a class action against Regence BlueShield, Washington's largest insurer, alleging that the insurer's denial of prescription contraceptive drug coverage violates antidiscrimination laws. See American Civil Liberties Union \& Washington State National Abortion Reproductive Rights Action League $v$ Regence BlueShield, Docket No 01-2-19623-5SEA (W D Wash) (filed July 12, 2001). Employees of Wal-Mart have brought a similar class action. See Mauldin $v$ Wal-Mart Stores, Inc, Docket No 101 CV-2755 (N D Ga) (filed Oct 16, 2001); Wal-Mart Sued for Excluding Prescription Contraceptives from Employee Health Plans, National Women's Law Center News Room (Oct 17, 2001), available online at $<\mathrm{http}: / \mathrm{www} . n$ wlc.org/details.cfm?id $=906 \&$ section=newsroom $>$ (visited Feb 22,2002) (detailing the lawsuit).

161 See Bob Jones University v United States, 461 US 574, 604 (1983) ("[T]he Government has a fundamental, overriding interest in eradicating racial discrimination in education ... [which] substantially outweighs whatever burden denial of tax benefits places on [the nonprofit private school petitioners'] exercise of their religious beliefs.").

162 See, for example, Bowen v Roy, 476 US 693, 709 (1986) (holding that the government's interest in preventing fraud in Social Security benefits is sufficient to compel Native Americans to use Social Security numbers against their religious beliefs); United States $v$ Lee, 455 US 252, 258-59 (1982) (holding that assuring mandatory participation in the Social Security system is sufficient to override religious rights of the Amish). 
if the government has a compelling interest in protecting the tax system, and in protecting animals, ${ }^{163}$ its interest in ending hazardous and discriminatory health practices against women should also be considered compelling. Based on the Court's holdings that eradicating discrimination is compelling enough to override First Amendment rights $^{164}$ and given the lack of standards for what courts classify as "compelling,", eradicating gender discrimination should be considered a compelling interest sufficient to override a religious liberty. ${ }^{160}$

Supreme Court precedent thus indicates that eradicating gender discrimination is a compelling government interest. Because failing to provide contraceptive coverage while covering other prescription drugs and preventive health services are covered constitutes gender discrimination, contraceptive coverage laws fulfill the first part of the strict scrutiny test. That is, the need for women to receive equal insurance benefits justifies both the law's imposition and its selective exemptions. ${ }^{167}$

\section{Enacted selective exemptions are narrowly tailored.}

Under the second prong of the strict scrutiny test, a law must be narrowly tailored to serve the compelling interest. ${ }^{16 s}$ For statutory exemptions to be narrowly tailored, the distinction between which groups are exempted and which are not must "tightly fit" with the government's compelling interest. ${ }^{169}$ Selective exemptions distinguish solely on the basis of type of organization. ${ }^{170}$ As discussed in Part

163 See, for example, United States v Jim, 888 F Supp 1058, 1062-64 (D Or 1995) (finding a compelling interest in protecting endangered eagles).

164 See note 154 and accompanying text.

165 See notes 34-37 and accompanying text.

166 See Thomas $v$ Anchorage Equal Rights Commission, 165 F3d 692, 714-15 (9th Cir 1999) (noting that eradicating gender discrimination is a sufficiently compelling interest to override religious liberties), opinion withdrawn on other grounds, 192 F3d 1208 (9th Cir 1999); EEOC $v$ Fremont Christian School, 781 F2d 1362, 1368-69 (9th Cir 1986) (finding that a school's gender discrimination in provision of health insurance was not protected by the Free Exercise Clause).

167 Contraceptive coverage laws also serve the state's interest in protecting women's reproductive rights and the right to control family matters. A forceful argument can be made that this state interest is compelling based on Supreme Court decisions holding that reproductive freedom is protected by the Constitution. See, for example, Griswold v Connecticut, 381 US 479, 48586 (1965) (holding that forbidding the use of contraceptives impermissibly intrudes upon the constitutionally protected right of marital privacy); Eisenstadt $v$ Baird, 405 US 438, 446-55 (1972) (extending Griswold to unmarried couples on equal protection grounds). The Court, however, has not yet had a chance to determine whether this reproductive interest is "compelling."

168 Lukumi, 508 US at 531-32; Sherbert, 374 US at 406.

169 See note 144.

170 Selective exemptions in contraceptive coverage laws do not discriminate on their face on the basis of religious denomination. Section 3121 selective exemptions, which only exempt a "church or qualified church-controlled organization," appear to favor Christian religions but are in fact neutral because a "church" includes equivalents in other religions. See note 90 and accompanying text. Purpose/membership selective exemptions, as well as Washington's exemption, 
IV.B.1, providing an exemption to all religious groups would detract from the goal of eradicating gender discrimination, because fewer women would be granted contraceptive coverage. In the case of contraceptive coverage laws, this distinction must serve the interest in ending gender discrimination in insurance practices. The state may make distinctions, but the question of narrow tailoring concerns how these states make these distinctions. This part of the free exercise inquiry is the most difficult to assess because the Court has provided the least guidance. The few courts that have correctly applied strict scrutiny to laws with exemptions held the laws at issue did not fulfill a compelling interest and never reached the narrow tailoring prong. ${ }^{171}$

This Part proposes a framework to determine when an exemption is narrowly tailored. First, an exemption that attempts to differentiate only between those religious organizations that are primarily religious and those that are not is constitutional because this categorical exemption has been implicitly approved by the Court. Second, if the scope of an exemption is narrowed further than this approved category by additional requirements for eligibility, then the state must show how the exemption's specific requirements fulfill the compelling interest of ending gender discrimination.

Section 3121 exemptions apply to a "church or a qualified churchcontrolled organization," ${ }^{\prime \prime 2}$ leaving out religious organizations that are not closely linked to a church. These types of exemptions attempt to draw a distinction between those organizations that have purely religious goals ("exclusively religious organizations"), such as a church or synagogue, and those organizations that are religiously affiliated but also have secular goals ("quasi-religious organizations"), such as Catholic Charities, which primarily provide services to the underprivileged. The Court has not specifically addressed whether a court (or, in this case, a legislature) may inquire as to whether religion itself is central to an organization when granting an exemption.

do not discriminate against types of religions because they only refer to "religious employers," and the other prongs of the definition have nothing to do with religious orientation (for example, tax exempt status). See notes 94-101 and accompanying text.

171 See, for example, Fraternal Order of Police, 170 F3d at 365-67 (finding no compelling interest in police department refusing to grant an exemption for Muslim officers from a policy requiring that all officers shave their beard); Keeler v Mayor and City Council of Cumberland, 940 F Supp 879, 886-87 (D Md 1996) (finding no compelling interest in not exempting religious organization from historic preservation law).

172 See, for example 1999 Conn Acts 99-79, $\$ \$ 1(f), 2(f)$ (Reg Sess).

173 See Smith, 494 US at 887 (" $[1] \mathrm{t}$ is not within the judicial ken to question the centrality of particular beliefs or practices to a faith, or the validity of particular litigants' interpretations of those creeds.") (citation omitted). Smith held that a court may not inquire whether a particular belief is central to a religion. See id. 
The Court has, however, implicitly held such distinctions to be constitutional. In Walz $v$ Tax Commission of the City of New York, ${ }^{174}$ the Court upheld a property tax exemption for realty owned by associations organized exclusively for religious purposes and for carrying out such purposes. ${ }^{175}$ The Court focused solely on whether there was a sufficient state interest to distinguish between religious and nonreligious groups, finding sufficient the interest in fostering "beneficial and stabilizing influences in community life." as to whether the exemption's distinction between quasi-religious and exclusively religious organizations "fit" with this interest." The Court assumed that such a distinction posed no constitutional objection, regardless of whether it fit with the state's interest. ${ }^{\text {tro }}$ Such a distinction actually does not fit the state interest because quasi-religious organizations also exert "beneficial and stabilizing" influences in the community. ${ }^{179}$ Lower court cases have also upheld similar exemptions, such as exemptions for "churches and qualified church-controlled organizations" and entities "organized and operated exclusively for religious purposes," without inquiring whether the distinction was narrowly tailored to fulfill the government interest. ${ }^{\mathrm{is}}$ Although the specific language of the exemptions upheld by lower courts is different than the exemption upheld in Walz, the aim of these exemptions is the same: to

174397 US 664 (1970).

175 Id at 673 .

176 Id.

177 See id at 672-73. Although Walz was pre-Smith, it was post-Sherbert. Courts analyzing free exercise claims were applying the strict scrutiny test at that time. Although Walz found a compelling state interest it did not use the narrow tailoring test. See id. Walz's rationale was based exclusively on Establishment Clause analysis. See id at 671-80. However, the Court held that the exemption not only complied with the Establishment Clause but also comported with the Free Exercise Clause, offering little rationale for the latter holding. See id at 664,680 (holding that the exemption at issue was "not a violation of the Religion Clauses of the First Amendment") (emphasis added). If the Court had analyzed the exemption under the Free Exercise Clause, it would have noticed groups like Catholic Charities that are not organized "exclusively for religious purposes" and therefore not exempted from the law.

178 See id.

179 By failing even to ask whether such a distinction is constitutional, the Court has implied that the religious rights of some types of organizations are more protected than the rights of others, provided, of course, that the distinction is denominationally neutral.

180 See, for example, Bethel Baptist Church v United States, 629 F Supp 1073, 1080-87 (M D Pa 1986) (holding that 26 USC § 3121 of the tax code, exempting "churches and churchcontrolled organizations" from certain taxes on wages, violates neither the Establishment Clause nor the Free Exercise Clause, without questioning whether quasi-religious organizations should also be exempt); Goldsboro Christian Schools, Inc v United States, 436 F Supp 1314, 1317 (E D NC 1977) (holding that 26 USC $\$ 501$ (c)(3), which exempts organizations "operated exclusively for religious purposes," does not violate the Free Exercise Clause, without addressing the distinction among religious organizations). Although these cases were pre-Smith, they were decided under the strict scrutiny test (the test that would apply to contraceptive coverage laws with selective exemptions) and are therefore good law in this context. 
exempt only those organizations that are primarily religious. ${ }^{181}$ Thus, laws that make this same type of distinction do not need to be narrowly tailored as long as the court finds a compelling interest-they are presumptively narrowly tailored.

Section 3121 exemptions use the same exact language that lower courts found constitutional. ${ }^{183}$ Rhode Island's and Massachusetts's exemptions do not add additional requirements to this language and are therefore constitutional. ${ }^{184}$ Connecticut's law adds to the exempted category a "church-affiliated organization." actually broadens the exempted class and is therefore constitutional. Maine's law adds a requirement that the organization be "organized and operated exclusively for religious purposes." This language is similar to that upheld in $\mathrm{Walz}^{1187}$ and is therefore constitutional as well. Thus, all Section 3121 exemptions are constitutional; they are presumptively narrowly tailored because they have already been approved.

Purpose/membership exemptions, however, go beyond the approved distinction between quasi-religious and exclusively religious organizations by imposing additional requirements of organizational purpose, employment demographics, and beneficiary demographics. ${ }^{1 \$ s}$ Some of these additional requirements may be merely rephrasing the distinction between quasi-religious and exclusively religious organizations. However, if they are not attempts to grasp the same categorical

181 If the distinction between exclusively religious and quasi-religious organizations is impermissible, then exemptions in the tax code itself, 26 USC $\$ 3121$, would be unconstitutional.

182 It could be argued that Walz implies that any distinction based solely on type of religious organization, not just a distinction based on whether the organization is primarily religious (for example, California's exemption), is permissible. The failure even to ask whether such a distinction is constitutional may indicate that the Court believes that distinctions based on type of organization do not create free exercise concerns. For example, it is permissible to distinguish between a Catholic church and Catholic Charities because they are both of the same religious affiliation. However, it would be impermissible to distinguish between a Lutheran church and a Catholic church because they are of different religious affiliations.

This conception of free exercise rights allows those who lead the Catholic church to have greater rights than those who direct Catholic Charities. But the free exercise right is also an individual right. The state cannot force the individuals who direct Catholic Charities to violate their religious beliefs on contraception, yet allow the individuals who lead a Catholic church to be exempted and therefore not forced to violate their religious beliefs, unless such a distinction fulfills a compelling interest and is narrowly tailored to do so. Thus, Walz should not be extended to hold that all distinctions based on type of organization are constitutional.

183 See notes 88-93 and accompanying text.

184 See 26 USC \$ 3121(w); RI Gen Laws \$\$ 27-18-57, 27-19-48, 27-20-43, 27-41-59; Mass Gen Laws Ann ch $175 \S 47 \mathrm{~W}$ (West 2002). See also notes 89-90 and accompanying text.

185 See 1999 Conn Acts 99-79, §§ 1(e)-(f), 2(e)-(f) (Reg Sess). See also note 92.

186 See Me Rev Stat Ann $\$ \$ 2756(2), 2847-G(2), 4247(2) ; 26$ USC $\$ 501$ (c). See also note 93.

187 See notes 174-178 and accompanying text.

18 See notes $94-99$ and accompanying text. 
distinction, then they must be narrowly tailored to fulfill the specific compelling interest of ending gender discrimination. ${ }^{100}$

In the case of contraceptive coverage laws, the state's compelling interest is in ending gender discrimination in the insurance context by granting employees needed access to contraceptives. The goal of ending gender discrimination is specifically targeted toward female employees. ${ }^{190}$ Thus, purpose/membership exemptions' additional restrictions on eligibility should distinguish only between those organizations that employ women who want and need access to prescription contraceptives and those that employ women who do not. If an employee does not want contraceptive benefits because she shares the values of her religious employer, the need to alleviate gender discrimination is not as compelling as when a woman needs contraceptives but is denied such benefits because the actual individual employer does not want to provide the benefits. ${ }^{191}$ Thus, purpose/membership exemptions are constitutional as long as they focus on whether the employee actually desires contraceptive coverage.

The North Carolina law was the first purpose/membership exemption to be enacted. ${ }^{192}$ The first three prongs of eligibility for the exemption distinguish between those organizations that are exclusively religious and those that are not. First, the entity must be operated for religious purposes. This prong is a weaker restriction on gender discrimination than was the approved exemption in Walz for organizations with "exclusively" religious purposes. This prong is therefore constitutional. Second, the entity must fit the definition of 26 USC $\S$ $501-$ it must be "organized and operated for exclusively religious purposes." ${ }^{13}$ This language has been approved by lower courts ${ }^{104}$ and uses Walz's wording of "exclusive" religious purposes. Thus, this prong is constitutional. The third prong is that the entity's primary purpose must be the inculcation of religious values. Although "inculcation" is narrower than "operated for religious purposes," this requirement still focuses on whether the organization is exclusively religious in nature. This prong is therefore constitutional, as well.

The final prong of the North Carolina exemption requires that the entity primarily employ persons who share its religious tenets. This prong may be an indirect method of determining whether an organi-

189 See notes 33-37 and accompanying text.

190 See notes 62-66, 153-160 and accompanying text.

191 However, when employers and insurers fail to provide contraceptive benefits, gender discrimination is still occurring in the field of insurance benefits even if an individual employee does not want the benefit.

192 See NC Gen Stat § 58-3-178(e); note 94.

193 See 26 USC $\$ 501$.

194 See notes 181-182 and accompanying text. 
zation is purely religious on the theory that exclusively religious organizations tend to hire employees of its own faith. This prong is also directly related to the specific compelling interest of eradicating gender discrimination against employees by providing them with needed contraception. An employee who shares the organization's belief against the use of contraceptives would not want contraceptive benefits. Because she does not want contraceptive benefits, she is not personally negatively affected by her employer's choice not to provide such benefits. Thus, North Carolina's exemption is narrowly tailored because the first three prongs focus on the Court-approved categorical distinction between those organizations that are exclusively religious and those that are not, and the fourth prong focuses on the compelling interest of eradicating gender discrimination against employees who seek access to contraceptive benefits.

The Hawaii exemption, which removes the organizational requirement and adds a requirement that the entity not be staffed by public employees, ${ }^{109}$ is also narrowly tailored. The added prong of public employees merely assures that the state is not involved in any gender discrimination.

The California exemption is also narrowly tailored. First, it requires tax-exempt status under a different section of the Internal Revenue Code, 26 USC $\$ 6033$, which only applies to "churches, their integrated auxiliaries, or exclusively religious organizations." ${ }^{\text {"196 }}$ This prong is a mix of the language of Section 3121 exemptions and the exemption at issue in Walz, ${ }^{190}$ relating to whether an organization is purely religious. It is therefore permissible. Second, the California law replaces the religious organization requirement with a requirement that the organization serve primarily persons who share its religious tenets. ${ }^{198}$ This prong attempts to discern whether the organization is exclusively religious on the theory that an organization that serves all those in need is not exclusively religious. Thus, this prong also focuses on whether the organization is exclusively religious. The Arizona exemption mirrors three of the four prongs of the California exemption. ${ }^{198}$ Thus, based on the above analysis of the California exemption, the Arizona exemption is also narrowly tailored.

Thus, all selective exemptions are narrowly tailored because they either use language similar to the Court-approved exempted category

195 See Hawaii Rev Stat § 431:10A-116.7; note 96.

196 See Cal Health \& Safety Code $\S 1367.25(\mathrm{~b})$; note 98 . See also 26 USC $\S \S 6033(\mathrm{a})(2)(\mathrm{A})(\mathrm{i})$,(iii).

197 See note 175 and accompanying text.

198 See note 98.

199 Compare Ariz Rev Stat $\S \S 20-826,20-1057.08(F)$, with Cal Health \& Safety Code $\$ 1367.25(b)$. See also notes $98-99$. 
of "exclusively religious organizations" or add additional requirements that are directly related to the compelling interest of eradicating gender discrimination in insurance practices against female employees.

\section{CONCLUSION}

When assessing the constitutionality of statutory exemptions, courts have focused exclusively on whether they violate the Establishment Clause, completely missing the potential free exercise claim available to employers and insurers. Under the Free Exercise Clause, exemptions that apply to some, but not all, individuals or religious entities must be justified by a compelling interest and narrowly tailored to fit that interest. Although contraceptive coverage laws impose a significant burden on religious employers by forcing them to commit what they believe to be a sin, religious freedom is not absolute. In the case of contraceptive coverage laws, the rights of religious employers must be subordinated to the need to end gender discrimination in the context of insurance benefits. Thus, assessing the constitutionality of contraceptive coverage laws depends on the existence and scope of religious exemptions.

Contraception coverage laws without exemptions, such as those of Georgia, Iowa, New Hampshire, and Vermont, are generally applicable because they apply to all employers and/or insurers. Such laws are constitutional and will only fail to comport with Smith if there is evidence, as in Lukumi, that the law was not neutral and the legislature actually intended to suppress religious freedom. Contraceptive coverage laws with broad exemptions that exempt all religious entities do not violate the free exercise rights of religious employers because they allow any entity to self-identify as religious and opt out if it has a belief against contraception. Contraceptive coverage laws with selective exemptions that exempt some religious entities but not others, however, are not generally applicable because they do not apply to all employers and/or insurers. They must therefore pass strict scrutiny.

Under strict scrutiny, a court must first assess whether the law and its exemption scheme serve the compelling interest of ending gender discrimination. This question will usually be answered in the affirmative. The court must then ask whether the exemption is narrowly tailored to serve those interests. A selective exemption is constitutional if either (1) it attempts to differentiate between exclusively religious and quasi-religious organizations, or (2) it adds additional restrictions necessary to eradicate gender discrimination. Selective exemptions such as those of Rhode Island, Massachusetts, Connecticut, 
Maine, North Carolina, Hawaii, California, and Arizona have achieved this delicate balance and therefore are constitutional. 


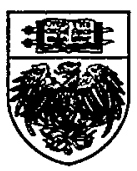

